\title{
MENINGKATKAN KETERAMPILAN GURU MEMBUKA DAN MENUTUP PELAJARAN MELALUI SHARING PENGALAMAN MENGAJAR DALAM FORUM KKG
}

\author{
Maman \\ Dinas Pendidikan Kota Tasikmalaya, Jl. Ir H Juanda No.188, Sukamulya, Tasikmalaya, Indonesia \\ Email: mamannnn1403@gmail.com
}

\begin{abstract}
The focus of this action research is to explore the benefits of sharing teaching experiences in the KKG forum for increasing opening and closing of the lessons and the teachers' mastery on the concepts of the subjects in SD Negeri 1 Karangsambung, Cibeureum District, Tasikmalaya City. The method used in this research is experimental. tbhe researcher gives certain treatment. The subjects of this study are teachers participating inm the KKG consisting of 8 teachers at SD Negeri 1 Karangsambung, Cibeureum District, Tasikmalaya City. Based on the results of the study, it can be concluded that sharing teaching experiences in the KKG forum has benefits in increasing the ability to open and close lessons. This can be seen by all teachers who are being able to bring up all aspects of opening lessons, namely attracting students' attention, motivating students, providing references or limitations and making links with previous material, also 3) all teachers are able to bring up all aspects of closing lessons, namely reviewing, evaluating, and informing the next material by showing the time spent opening the lesson is increasing, respectively from observation.
\end{abstract}

Keywords: Teacher Skills, Sharing, KKG Forum

\section{ABSTRAK}

Fokus Penelitian Tindakan Sekolah ini adalah mencoba menggali manfaat sharing pengalaman mengajar dalam forum KKG bagi peningkatan membuka dan menutup pelajaran serta penguasaan konsep guru dalam mata pelajaran SD Negeri 1 Karangsambung Kecamatan Cibeureum Kota Tasikmalaya. Metode yang digunakan dalam penelitian ini adalah eksperimen karena pada peneliti memberikan perlakuan tertentu. Subyek penelitian ini adalah guru-guru peserta KKG yang terdiri dari guru di SD Negeri 1 Karangsambung Kecamatan Cibeureum Kota Tasikmalaya sebanyak 8 orang. Berdasarkan hasil penelitian dapat disimpulkan bahwa,:1) Sharing pengalaman mengajar dalam forum KKG bermanfaat dalam meningkatkan kemampuan membuka dan menutup pelajaran. Hal ini terlihat dari fakta-fakta bahwa semua guru mampu memunculkan semua aspek membuka pelajaran yaitu menarik perhatian siswa, memotivasi siswa, memberi acuan atau batasan serta membuat kaitan dengan materi sebelumnya; dan 2) semua guru mampu memunculkan seluruh aspek menutup pelajaran yaitu meninjau kembali, mengevaluasi, dan menginformasikan bahan berikutnya dengan menunjukkan waktu yang digunakan untuk membuka pelajaran semakin bertambah, secara berturut-turut dari observasi.

Kata Kunci: Keterampilan Guru, Sharing, Forum KKG

Cara sitasi: Maman. (2020). Meningkatkan Keterampilan Guru Membuka dan Menutup Pelajaran melalui Sharing Pengalaman Mengajar dalam Forum KKG. J-KIP (Jurnal Keguruan dan IImu Pendidikan), 1 (2), 99-104. 


\section{PENDAHULUAN}

Salah satu reformasi bidang pendidikan adalah meningkatkan mutu pengajar atau pendidik agar menghasilkan output yang bermutu dan mampu bersaing dengan negara-negara maju. Dalam rangka meningkatkan kompetensi mengajar guru SD agar dapat menyesuaikan diri dengan perkembangan ilmu pengetahuan dan kemajuan teknologi yang semakin pesat, maka perlu dilakukan peningkatan kompetensi guru. Peningkatan kompetensi dimaksudkan untuk memperluas pengetahuan dan meningkatkan keterampilan mengajar. Hal tersebut dapat dilakukan melalui berbagai kegiatan, baik yang diupayakan oleh guru-guru sendiri maupun yang diupayakan oleh pimpinannya (kepala sekolah dan pengawas).

Proses belajar-mengajar yang berkualitas adalah guru yang memiliki kompetensi mengajar yang memadai dalam hal merencanakan dan mengelola kegiatan belajar mengajar, serta menilai hasil belajar siswa. Guru sebagai pengajar berperan dalam merencanakan dan melaksanakan pembelajaran. Oleh sebab itu guru dituntut untuk menguasai seperangkat pengetahuan dan keterampilan mengajar.

Guru merupakan komponen penting dalam upaya peningkatan mutu pendidikan nasional. Guru yang berkualitas, profesional dan berpengetahuan, tidak hanya berprofesi sebagai pengajar, namun juga mendidik, membimbing, mengarahkan, melatih, menilai dan mengevaluasi peserta didik. Berdasarkan Standar Nasional Kependidikan, guru harus memiliki empat kompetensi dasar yaitu kompetensi pedagogis, kompetensi sosial, kompetensi kepribadian, dan kompetensi profesional. Namun, kompetensi-kompetensi yang dimiliki guru saat ini masih terbatas, sehingga diperlukan suatu upaya untuk mengoptimalkan kompetensi-kompetensi tersebut. Guru dapat dinilai profesional ketika dia melakukan pengembangan wawasan dan ilmu, mampu menelaah secara kritis, serta kreatif dan inovatif dalam menyampaikan materi.

Para pengamat pendidikan menilai bahwa kualitas kemampuan profesionalisme guru SD belum memadai. Karena itu perlu terus ditingkatkan. Berbagai studi tentang kualitas guru, menyimpulkan bahwa kemampuan profesionalisme guru menguasai bahan pelajaran memberikan efek yang positif terhadap prestasi belajar. Menurut Saud (2007) penelitian dalam bidang pendidikan kependidikan di Indonesia menunjukkan bahwa 26, $17 \%$ dari hasil belajar siswa dipengaruhi oleh penguasaan guru dalam hal materi pelajaran.

Berkaitan hal itu Purwanto (Kotten, 2005) mengemukakan kekurangmampuan guru SD menguasai bidang studi antara lain disebabkan oleh standar kualitas kelulusan guru yang menurun, sikap dan cara mengajar guru yang tidak berubah-ubah selama bertahun-tahun mengajar. Banyak guru yang tidak pernah berupaya meningkatkan pengetahuan dan kemampuannya sehingga sulit menyesuaikan diri dengan perkembangan ilmu dan teknologi.

Menurut Widodo (2007) kenyataan banyak ditemukan di banyak sekolah guru belum mampu melaksanakan salah satu keterampilan dasar mengajar yaitu membuka dan menutup pelajaran, karena hakikat dari membuka pelajaran adalah kemampuan guru untuk menciptakan suasana siap mental dan menimbulkan perhatian siswa agar terpusat pada hal-hal yang akan dipelajari.

Sedangkan menutup pelajaran adalah kegiatan yang bersifat memberikan umpan balik bagi siswa segera setelah pembelajaran usai serta memberikan penguatan maupun revisi terhadap segala sesuatu yang menjadi pengalaman belajar saat itu. Membuka dan menutup pelajaran merupakan salah satu dari beberapa keterampilan pembelajaran yang menjadi satu kesatuan yang tidak dapat dipisahkan satu dengan yang lainnya. Seperti dimaklumi, bahwa sudah sejak lama praktik pembelajaran pada umumnya cenderung dilakukan secara konvensional yaitu melalui teknik komunikasi oral. Praktik pembelajaran konvensional semacam ini lebih cenderung menekankan pada bagaimana guru mengajar (tealcher-centre) dari pada bagaimana siswa belajar (student-centre), dan secara keseluruhan hasilnya dapat kita maklumi yang ternyata tidak banyak memberikan kontribusi bagi peningkatan. 
Keadaan kualitas pendidikan seperti ini, menimbulkan keluhan dan kritikan dari berbagai kalangan masyarakat yang dialamatkan kepada guru. Hal ini didasarkan pada pertimbangan bahwa guru merupakan komponen yang layak mendapat perhatian, karena baik ditinjau dari posisi yang ditempati dalam struktur organisasi pendidikan maupun dilihat dari tugas yang diemban, guru merupakan pelaksana operasional terdepan yang menentukan dan mewarnai proses belajarmengajar. Guru merupakan pusat dari produktivitas sekolah. Guru merupakan kunci bagi seluruh upaya pendidikan dan peningkatan mutu pendidikan. Guru merupakan satu-satunnya komponen yang dapat merubah komponen-komponen lainnya menjadi bervariasi.

Upaya meningkatkan kompetensi guru dapat dilakukan dengan beberapa pendekatan, yakni pendekatan internal dengan memanfaatkan guru yang lebih berpengalaman sebagai pelatih, pendekatan eksternal dengan mengirimkan guru untuk mengikuti pelatihan ataupun studi lanjut, dan dengan pendekatan kemitraan melalui kerjasama antara perguruan tinggi dan sekolah. Karakteristik program kemitraan adalah dikembangkannya prinsip kolaborasi yang memberikan keuntungan pihakpihak yang terlibat. Prinsip kolaborasi juga dapat dilakukan antar sesama guru dalam suatu sekolah juga dapat menjadi ajang yang efektif untuk meningkatkan mutu guru.

Melalui sharing pengalaman mengajar dalam forum KKG, antara guru-guru dalam sekolah, bertujuan agar para guru bergabung dalam satu kelompok saling tukar menukar pikiran dan pengalaman mengajar, saling membantu sesama guru, mengatasi kesulitan-kesulitan yang dihadapi dalam pengelolaan kegiatan belajar-mengajar (Satori, 1980). Jadi KKG merupakan suatu wadah tempat berhimpunnya guru-guru untuk membahas berbagai hal yang berhubungan dengan proses belajar-mengajar. Melalui forum KKG ini juga bisa diselenggarakan belajar bersama dalam pengajaran, dalam hal ini bukan hanya guru yang melaksanakan pembelajaran saja yang dapat memetik manfaat, namun terlebih lagi rekan sejawat yang hadir pada saat pembelajaran. Dengan mengamati kegiatan pembelajaran yang dilakukan seorang guru, pengamat didorong untuk merefleksikan pembelajaran yang dilaksanakannya dan serta memikirkan bagaimana meningkatkan kualitasnya. Oleh karena itu forum KKG ini sesungguhnya merupakan forum belajar bersama untuk saling belajar dari pengalaman mengajar guna meningkatkan kualitas pembelajaran.

Berpijak dari adanya kesadaran dan keinginan untuk meningkatkan SDM maka peranan guru khususnya di SD perlu diperkuat dan didukung oleh tersedianya tenaga kependidikan yang berkualitas yaitu guru yang sehingga dapat melaksanakan tugasnya, baik dalam merencanakan, melaksanakan, maupun mengevaluasi kegiatan belajar mengajar, serta terus berupaya mengembangkan diri sesuai kebutuhan perkembangan zaman.

Untuk merubah kebiasaan praktik pembelajaran dari pembelajaran konvensional ke pembelajaran yang berpusat kepada siswa memang tidak mudah, terutama di kalangan guru yang tergolong pada kelompok laggard (penolak perubahan/inovasi). Dalam hal ini, melalui sharing pengalaman mengajar dalam forum KKG tampaknya dapat dijadikan sebagai salah satu alternatif guna mendorong terjadinya perubahan dalam praktik pembelajaran di Indonesia menuju ke arah yang jauh lebih efektif. Hal ini sesuai pendapat Oliva (1984) bahwa upaya pengembangan tingkat pengetahuan dan keterampilan mengajar dapat dilakukan melalui in-service training.

Dari kenyataan diatas maka diperlukan sebuah alternatif untuk peningkatan kemampuan kompetensi mengajar guru dalam peningkatan kompetensi selain dalam bentuk pelatihan, salah satunya adalah dengan forum KKG sebagai salah satu alternatif guna mendorong terjadinya perubahan dalam praktik pembelajaran menuju ke arah yang jauh lebih efektif, juga merupakan salah satu upaya untuk meningkatkan proses dan hasil pembelajaran yang dilaksanakan secara kolaboratif dan berkelanjutan oleh sekelompok guru (Mulyasa, 2007).

Refleksi guru terhadap rekaman pembelajarannya dapat menemukenali kelebihan dan kekurangannya sehingga memungkinkan ada perubahan cara mengajar guru setelah melakukan refleksi atas pembelajaran mereka yang direkam melalui video (Widodo, 2007). Tentunya semakin banyak refleksi itu dilakukan diharapkan akan mampu lebih memperbaiki profesionalisme guru dalam 
melaksanakan pembelajaran. Ini berarti metode ini dapat menjadi alternatif bagi peningkatan mutu pendidikan. Pendidikan seyogianya diarahkan untuk mengembangkan individu-individu yang melek sains (scientific literacy) yang meliputi pengetahuan tentang usaha ilmiah dan aspek-aspek fundamental tentang konsep, prinsip serta keterampilan ilmiah untuk memecahkan masalah seharihari dan dalam pengambilan keputusan (Amin, 1997).

Dalam hal ini Buchori (2007) menyatakan bahwa menciptakan masyarakat yang menguasai teknologi inovatif baik dibidang produksi maupun konsumsi, hanya dapat diwujudkan apabila kepada mereka diberikan dasar kemampuan yang mencukupi meliputi kemampuan: kognitif, keterampilan, sikap, atau nilai-nilai. Berkaitan dengan hal tersebut Abruscato (1982) menyatakan bahwa tujuan khusus pendidikan Sains harus mencakup tiga domain yang meliputi: kognitif, afektif, dan psikomotor. Ada beberapa pihak yang beranggapan bahwa pembelajaran harus lebih ditekankan dalam mengembangkan potensi manusia, karena dianggap mampu melatih orang berpikir secara logis dan sistematis. Pada hakikatnya pembelajaran Sains harus ditekankan pada tiga hal yaitu produk, proses, dan sikap. Berdasarkan latar belakang dan fokus masalah yang telah dipaparkan, maka masalah yang akan diteliti dirumuskan dalam bentuk pertanyaan sebagai berikut: "Sejauh manakah sharing pengalaman mengajar dalam forum KKG dapat meningkatkan keterampilan guru membuka dan menutup pelajaran?".

\section{METODE PENELITIAN}

Metode yang digunakan dalam penelitian ini adalah eksperimen. Pada desain ini peneliti memberikan perlakuan tertentu. Setelah itu pengukuran dilakukan lagi untuk kedua kalinya, dengan cara memberikan tes akhir (postest), yang mana fungsinya untuk melihat hasil dari perlakuan yang diberikan. Subyek penelitian ini adalah guru-guru peserta KKG yang terdiri dari guru SD Negeri 1 Karangsambung Kecamatan Cibeureum Kota Tasikmalaya. Pengumpulan data dalam penelitian ini dilakukan oleh peneliti sendiri dengan memasuki lapangan. Adapun tehnik pengumpulan data atau informasi untuk membahas mengenai manfaat sharing pengalaman mengajar dalam forum KKG bagi peningkatan membuka dan menutup pelajaran. Prosedur penelitian dilaksanakan melalui tiga tahap, yaitu: (1) tahap persiapan; (2) tahap pelaksanaan, dan (3) pengolahan dan analisis data

\section{HASIL DAN PEMBAHASAN}

Semua guru memiliki perubahan yang cukup menggembirakan setelah mengikuti sharing pengalaman mengajar di forum KKG, guru-guru tersebut sudah mampu memunculkan kegiatan menginformasikan bahan berikutnya. Bahkan dalam melakukan kegiatan memberikan informasi bahan berikutnya guru lebih bervariasi, terutama pada guru $A$, guru $B$, guru $E$, guru $F$, dan guru $G$ dengan meminta siswa mengerjakan soal tertulis (PR), membaca lagi materi yang sudah dipelajari dan yang akan dipelajari, membawa bahan yang akan dipraktekan pada pertemuan selanjutnya, bahkan pada guru $\mathrm{E}$ memberi tugas kepada siswa untuk membuat kliping yang berhubungan dengan sumber energi panas yang sudah diajarkan dan sumbernya boleh dari internet, televisi maupun media cetak, sedangkan pada guru $\mathrm{F}$ memberi tugas soal tertulis yang dikerjakan dirumah dengan berkelompok dan meminta siswa melakukan percobaan yang berkaitan dengan materi yang diajarkan di sekolah. Dengan gambaran seperti menunjukkan bahwa guru sudah melakukan usaha untuk menguatkan konsep dan memberikan kesempatan pada siswa untuk melakukan pendalaman maupun perluasan konsep secara mandiri. Tetapi pada kenyataannya, ada beberapa guru yang diamati terutama sebelum guru mengikuti sharing pengalaman mengajar di forum KKG belum memunculkan aspek ini, artinya guru belum memahami betul fungsi dari aspek menginformasikan bahan berikutnya hal ini tampak dari alokasi waktu yang digunakan oleh beberapa guru, yaitu guru C, D dan $\mathrm{G}$ sangat pendek yaitu $0-0,3$. Ini menggambarkan guru belum menganggap penting memberikan informasi kepada siswa yang menyangkut hal-hal yang harus dilakukan siswa setelah mempelajari konsep 
materi tersebut dan untuk mempersiapkan materi yang akan dipelajari berikutnya sehingga siswa tidak memiliki gambaran kaitan kegiatan pembelajaran yang satu dengan yang lainnya.

Dengan memunculkan semua aspek keterampilan membuka dan menutup pelajaran diharapkan proses pembelajaran menjadi lebih baik sehingga siswa lebih termotivasi untuk belajar khususnya pembelajaran IPA, dengan demikian diharapkan hasil belajar siswa lebih lebih baik lagi. Kegiatan membuka dan menutup pelajaran harus direncanakan dan disusun rapi karena kegiatan ini sangat penting dilakukan guru agar pembelajaran lebih efektif dan lebih bermakna, sehingga siswa dapat termotivasi dan dapat meningkatkan hasil belajar siswa. Perolehan hasil prestasi belajar siswa pada pembelajaran IPA di Sekolah Dasar dapat meningkat apabila kemampuan keterampilan membuka dan menutup pelajaran dapat ditingkatkan oleh guru dengan baik dan benar secara rutinitas.

Dalam forum KKG semua peserta di bina dan di arahkan agar dapat meningkatkan profesionalisme guru. Kegiatan pengayaan dan kesempatan yang diberikan kepada guru untuk mengajar IPA di SD dirasa sangat membantu untuk memantapkan kemampuan mereka dalam merencanakan dan melaksanakan pembelajaran di SD. Pada saat mengajarkan Sains di SD, para guru harus dapat mengintegrasikan konten Sains dengan cara mengajarkannnya, disamping itu mereka juga harus dapat menerapkan beberapa komponen keterampilan dasar.

\section{KESIMPULAN}

Berdasarkan hasil penelitian dapat disimpulkan bahwa sharing pengalaman mengajar dalam forum KKG mempunyai bermanfaat dapat meningkatkan kemampuan membuka dan menutup pelajaran. Hal ini terlihat dengan semua guru mampu memunculkan semua aspek dari membuka pelajaran yaitu menarik perhatian siswa, memotivasi siswa, memberi acuan atau batasan serta membuat kaitan dengan materi sebelumnya, juga semua guru mampu memunculkan semua aspek dari dari menutup pelajaran yaitu meninjau kembali, mengevaluasi, dan menginformasikan bahan berikutnya dengan menunjukkan waktu yang digunakan untuk membuka pelajaran semakin bertambah, secara berturut-turut dari observasi.

Berdasarkan hasil temuan penelitian dan refleksi, agar penelitian ini menjadi lebih baik maka dapat dikemukakan saran untuk meningkatkan kompetensi guru dalam pembelajaran IPA di Sekolah Dasar yakni: 1) Guru diharapkan selalu aktif mengikuti kegiatan KKG yang dibina dan dikembangkan sendiri melalui latihan secara kolaboratif. 2) Guru diharapkan terus menambah wawasan dan memperdalam materi yang akan diajarkan; 3) Diharapkan adanya kesadaran guru untuk saling sharing pengalaman mengajar; 4) Materi yang diprogramkan di KKG harus disesuaikan dengan kebutuhan guru-guru tersebut, terutama yang berhubungan dengan proses belajar mengajar, agar penguasaan konsep dan kemampuan keterampilan mengajar menjadi jauh lebih baik.

\section{REKOMENDASI}

Perlu diadakan penelitian lebih lanjut tentang sharing pengalaman mengajar dalam forum KKG untuk meningkatkan kemampuan membuka dan menutup pelajaran serta kemampuan penguasaan konsep dalam pembelajaran IPA, yang ditekankan pada efektifitas waktu untuk kegiatan membuka dan menutup pelajaran serta kemampuan penguasaan konsep guru terhadap kemampuan penguasaan konsep siswa yang dihubungkan dengan bagaimana guru menyampaikan konsep materi yang benar agar tidak terjadi miskonsep terhadap siswa.

\section{UCAPAN TERIMAKASIH}

Ucapan terima kasih ditujukan kepada subyek penelitian ini yaitu guru-guru peserta KKG yang terdiri dari guru SD Negeri 1 Karangsambung Kecamatan Cibeureum Kota Tasikmalaya yang telah mendukung pelaksanaan penelitian ini. 


\section{DAFTAR PUSTAKA}

Abruscato, J. (1982). Teaching Children Science. New Jersey: Prentice Hall, Inc.

Amin. (1997). Mengatasi Krisis Setengah Baya. Bandung : Sinar Baru.

Buchori, M. (2007). Buku Panduan Internalisasi Pendidikan karakter di Sekolah. Yogyakarta : Penerbit Diva Prees.

Kotten, N. B. (2005). Upaya Pengembangan Profesionalisme Guru Sekolah Dasar. Jurnal IImu Pendidikan, 12 (1), 1-14.

Mulyasa, E. (2007). Standar Kompetensi dan Sertifikasi Guru. Bandung: PT Remaja Rosdakarya.

Olivia, P.F. (1984). Supervision for Today's Schools. London : Pearson Longman.

Satori, D. (1980). Administrasi Pendidikan. Bandung: Fip IKIP.

Saud, U.S. (2009). Pengembangan Profesi Guru. Bandung: Alfabeta

Widodo, J. (2007). Supervisi Guru Mata Pelajaran Ekonomi di Indonesia: antara Teori dan Realita. Dinamika Pendidikan, 2 (2), 291-313. 